\title{
The Toxicity Exerted by the Antibiotic Sulfadiazine on the Growth of Soil Bacterial Communities May Increase over Time
}

\author{
Vanesa Santás-Miguel ${ }^{1,2}$, Laura Rodríguez-González ${ }^{1,2}$, Avelino Núñez-Delgado ${ }^{3}\left({ }^{\circledR}\right.$, \\ Montserrat Díaz-Raviña ${ }^{4}$, Manuel Arias-Estévez ${ }^{1,2}$ (D) and David Fernández-Calviño $1,2, *$ (D) \\ 1 Área de Edafoloxía e Química Agrícola, Facultade de Ciencias, Universidade de Vigo, \\ 32004 Ourense, Galiza, Spain; vsantas@uvigo.es (V.S.-M.); laura.rodriguez.gonzalez@uvigo.es (L.R.-G.); \\ mastevez@uvigo.es (M.A.-E.) \\ 2 CITACA-Clúster de Investigación e Transferencia Agroalimentaria do Campus Auga, Universidade de Vigo, \\ 32004 Ourense, Galiza, Spain \\ 3 Departamento de Edafoloxía e Química Agrícola, Escola Politécnica Superior de Enxeñaría, Universidade de \\ Santiago de Compostela, 15705 Lugo, Galicia, Spain; avelino.nunez@usc.es \\ 4 Departamento de Bioquímica del Suelo, Instituto de Investigaciones Agrobiologicas de Galicia (IIAG/CSIC), \\ 15705 Santiago de Compostela, Galicia, Spain; mdiazr@iiag.csic.es \\ * Correspondence: davidfc@uvigo.es
}

Received: 20 October 2020; Accepted: 24 November 2020; Published: 26 November 2020

\begin{abstract}
The toxicity exerted by the antibiotic sulfadiazine on the growth of soil bacterial communities was studied in two agricultural soils for a period of 100 days. In the short-term ( 2 days of incubation), the effect of sulfadiazine on bacterial growth was low (no inhibition or inhibition $<32 \%$ for a dose of $\left.2000 \mathrm{mg} \cdot \mathrm{kg}^{-1}\right)$. However, sulfadiazine toxicity increased with time, achieving values of $40 \%$ inhibition, affecting bacterial growth in both soils after 100 days of incubation. These results, which were here observed for the first time for any antibiotic in soil samples, suggest that long-term experiments would be required for performing an adequate antibiotics risk assessment, as short-term experiments may underestimate toxicity effects.
\end{abstract}

Keywords: leucine incorporation; risk assessment; sulfonamide; veterinary; microbial community

\section{Introduction}

In recent decades, veterinary antibiotics have been widely used as therapeutic agents and even as promoters of animal growth in farming activities. The annual consumption of antibiotics in the European Union and in the USA was approximately 10,000 tons, with half of total consumption being for livestock production in the case of the European Union [1]. Between 30 and 80\% of the veterinary antibiotics administered to animals are excreted in feces and urine as unaltered forms, reaching the terrestrial environmental due to repeated spreading of manure/slurry in agricultural lands [2]. Therefore, high amounts of antibiotics are spread on agricultural soils each year [3]. Among veterinary antibiotics, the group of sulfonamides is one of most important in relation to its use in pig production, and specifically in the European Union [4]. Moreover, sulfonamide antibiotics show a high persistence in manures and soils [5-7], and are considered among those that present a higher risk regarding vulnerability of EU soils [8]. Among them, sulfadiazine (4-amino-N-(2-pyrimidinyl) benzene sulfonamide) is one of the most frequently used in veterinary medicine, especially in pigs [9]. Sulfadiazine (SDZ) is a broad-spectrum antibiotic with effect on many bacterial groups [10-12], because it is a competitive inhibitor of the bacterial enzyme dihydropteroate synthetase, and therefore of folic acid synthesis. Therefore, once in the soil it may affect to many no-target bacteria, with undesirable 
side-effects of reducing soil and environmental quality. Thus, the presence of sulfadiazine in soils may decrease $\mathrm{N}$ mineralization [13], and soil microbes' enzymatic activity [14], as well as increase bacterial community tolerance to sulfadiazine [15], or increase the presence of antibiotic resistance genes in water bodies $[16,17]$.

Assessments focusing on decreasing risks (risk mitigation) are increasingly important in order to protect the biodiversity and ecological functioning of ecosystems. Since it is not easy to predict the relationship between the chemical structure of organic compounds and their effect on soil microbial communities [18], a broad range of toxicological tests should be conducted to determine the toxicity of different pollutants onto soil microorganisms. However, SDZ remains as an understudied antibiotic in relation to its implications in the eventual effects of soil pollution on microbial communities $[19,20]$. In addition, most of the available results are based on methods focusing on the quantification of parameters/properties such as soil respiration, enzymatic activities, or microbial community structure [21], which are techniques with clearly lesser sensitive potential to detect toxicity than bacterial growth $[22,23]$. Further, bacterial community growth rates have also been shown to be sensitive measurements to detect changes in other environmental conditions, like $\mathrm{pH}$ and heavy metal contamination $[24,25]$. Therefore, the effect of sulfadiazine on the growth of bacterial communities should be analyzed to study the effects of this antibiotic with a sensitive end-point, in order to provide evidence to enable management practices that can protect the soil ecosystem.

In addition to the direct effects of organic compounds on soil microbial communities, the persistence of these effects in the environment is also of importance. Organic compounds are subjected to physical, chemical, and biochemical processes in the soil, such as adsorption, degradation, and transformation [26], and hence their effects on soil microorganisms may change with time. The effect of time on toxicity can differ depending on the type of toxic compound, soil characteristics, or the toxicity test employed. Usually, toxicity will decrease with time due to dissipation of the compound [23,27-29]. However, an increased toxicity with time is also possible, as suggested for the herbicide mecoprop using soil respiration as toxicity test in an acid soil [30], and recently confirmed for terbutryn [31].

Taking all these facts into consideration, the aim of the present work was to evaluate the effect of the antibiotic SDZ on the growth of soil bacterial communities both short-term (direct toxicity) and over time. Two acid soils were used for the toxicity tests, and the ${ }^{3} \mathrm{H}$ leucine incorporation method was employed for the estimation of bacterial community growth in those soils. Therefore, this is the first study focusing on the effect of time on the toxicity exerted by the antibiotic sulfadiazine on bacterial community growth. The main objective of this research was to provide novel knowledge regarding risk assessment related to accumulation of antibiotics in agricultural soils.

\section{Material and Methods}

\subsection{Experimental Design}

In order to check the temporal effect of sulfadiazine on the growth of soil bacterial communities, two soil samples differing in their total carbon content were selected. For each of the two soils, aliquots of $252 \mathrm{~g}$ (dry weight) were placed into $500-\mathrm{mL}$ polypropylene jars and subsequently rewetted up to $60-80 \%$ of the water holding capacity, and incubated for 1 week at $22{ }^{\circ} \mathrm{C}$ in the dark. This incubation time was sufficient for the recovery of microbial activity of a dry soil after rewetting [32]. After microbial recovery, each soil was distributed in 36 polypropylene jars of $50 \mathrm{~mL}$ ( $7 \mathrm{~g}$ of soil into each jar), resulting in a total of 72 microcosms ( 36 per soil). Subsequently, different amounts of SDZ were added to the soil microcosms, reaching 12 different concentrations of SDZ $(0,0.002,0.01,0.03,0.12,0.5,2.0,7.8,31.3$, 125,500 , and $2000 \mathrm{mg} \cdot \mathrm{kg}^{-1}$ ) per soil, which was carried out per triplicate. Sulfadiazine was added to the soil microcosms using talc powder as a carrier, in order to equalize the amount of dry material added to each microcosm, thereby facilitating SDZ mixing with soil [33]. Then, the bottles were sealed and incubated for 100 days at $22{ }^{\circ} \mathrm{C}$ in the dark. During this period, bacterial community growth was 
estimated on each microcosm after $2,4,8,16,32,64$, and 100 days of incubation. The soil microcosms were aerated at the time of sampling by removing the lid for $30 \mathrm{~min}$, while the soil moisture was maintained by adding water when needed.

\subsection{Materials}

Sulfadiazine (CAS 68-35-9; $\geq 99.0 \%$ purity) was supplied by Sigma-Aldrich (Steinheim, Germany), and was used for performing the assessment of SDZ toxicity on the bacterial community in soil samples. Talc (CAS 14807-96-6) was supplied by Sigma-Aldrich (Steinheim, Germany).

The two selected soil samples were previously analyzed by Conde-Cid et al. [34]. They were sampled in A Limia, an agricultural area located in the southeast of Galicia (NW Iberian Peninsula). The soil samples were taken with an Edelman probe, at a depth of 0-20 cm, along two plots, sampling a total of 10 subsamples per plot (total amount of $2 \mathrm{~kg}$ of soil per sample). The subsamples collected in each plot were mixed into a single composite sample for each soil. Subsequently, once in the laboratory, the composite soil samples were air-dried, sieved through a 2-mm mesh, homogenized, and stored in polypropylene bottles until analysis.

\subsection{Characterization of Soils}

The proportions of sand (particle size $2-0.05 \mathrm{~mm})$, silt $(0.05-0.002 \mathrm{~mm})$, and clay $(<0.002 \mathrm{~mm})$ of the soils were determined by wet sieving for the size fractions greater than $0.05 \mathrm{~mm}$, and using the international pipette method for those smaller [35]. Soil $\mathrm{pH}$ was determined in water (soil ratio: 1:2.5), using a combined glass electrode [35]. Total carbon and total nitrogen were determined by elemental analysis in a LECO CHN-1000 (LECO Corporation, St. Joseph, MI, USA). Exchangeable basic cations ( $\mathrm{Ca}, \mathrm{Mg}, \mathrm{Na}$, and $\mathrm{K}$ ) were extracted with $0.2 \mathrm{M} \mathrm{NH}_{4} \mathrm{Cl}$ [36], while exchangeable Al was extracted with $1 \mathrm{M} \mathrm{KCl} \mathrm{[37],} \mathrm{and} \mathrm{then} \mathrm{determined} \mathrm{by} \mathrm{flame} \mathrm{atomic} \mathrm{absorption} \mathrm{(} \mathrm{Ca}, \mathrm{Mg}$, and $\mathrm{Al}$ ) or emission spectroscopy ( $\mathrm{Na}$ and $\mathrm{K}$ ). The effective cation exchange capacity (eCEC) was estimated as the sum of the exchangeable basic cations and Al. Available phosphorus was extracted using $0.5 \mathrm{M} \mathrm{NaHCO}_{3}$ and determined using the phosphomolybdic complex method [38].

Table 1 shows the main characteristics of the studied soils. Briefly, the soils were sandy loam (soil 1) and sandy clay loam (soil 2) in texture, and presented total carbon and nitrogen contents of 1.07 and $0.09 \%$ (soil 1), and 3.1 and $0.25 \%$ (soil 2). The $\mathrm{pH}$ values in water were 4.8 (soil 1) and 4.6 (soil 2), and eCEC values were 4.1 for soil 1 , and $5.3 \mathrm{cmol}_{\mathrm{C}} \cdot \mathrm{kg}^{-1}$ for soil 2 . The bioavailable phosphorus was 225 for soil 1 and $169 \mathrm{mg} \cdot \mathrm{kg}^{-1}$ for soil 2.

Table 1. General characteristics of the soils used.

\begin{tabular}{ccc}
\hline \multirow{2}{*}{ Parameter } & \multicolumn{2}{c}{ Soil } \\
\cline { 2 - 3 } & $\mathbf{1}$ & $\mathbf{2}$ \\
\hline Sand $(\%)$ & $70 \pm 2$ & $65 \pm 2$ \\
Silt $(\%)$ & $12 \pm 1$ & $13 \pm 1$ \\
Clay $(\%)$ & $18 \pm 1$ & $21 \pm 2$ \\
Texture & Sandy loam & Sandy clay loam \\
pH & $4.8 \pm 0.1$ & $4.6 \pm 0.1$ \\
$\mathrm{C}(\%)$ & $1.1 \pm 0.1$ & $3.1 \pm 0.2$ \\
$\mathrm{~N}(\%)$ & $0.09 \pm 0.01$ & $0.25 \pm 0.04$ \\
$\mathrm{Ca}_{\mathrm{e}}\left(\mathrm{cmol}_{\mathrm{c}} \cdot \mathrm{kg}^{-1}\right)$ & $1.53 \pm 0.06$ & $1.51 \pm 0.21$ \\
$\mathrm{Mg}_{\mathrm{e}}\left(\mathrm{cmol}_{\mathrm{c}} \cdot \mathrm{kg}^{-1}\right)$ & $0.41 \pm 0.03$ & $0.52 \pm 0.02$ \\
$\mathrm{Na}_{\mathrm{e}}\left(\mathrm{cmol}_{\mathrm{c}} \cdot \mathrm{kg}^{-1}\right)$ & $0.25 \pm 0.03$ & $0.21 \pm 0.01$ \\
$\mathrm{~K}_{\mathrm{e}}\left(\mathrm{cmol}_{\mathrm{c}} \cdot \mathrm{kg}^{-1}\right)$ & $1.27 \pm 0.14$ & $0.93 \pm 0.09$ \\
$\mathrm{Al}_{\mathrm{e}}\left(\mathrm{cmol}_{\mathrm{c}} \cdot \mathrm{kg}^{-1}\right)$ & $0.61 \pm 0.05$ & $2.16 \pm 0.07$ \\
$\mathrm{eCEC}\left(\mathrm{cmol}_{\mathrm{c}} \cdot \mathrm{kg}^{-1}\right)$ & $4.08 \pm 0.31$ & $5.33 \pm 0.40$ \\
$\mathrm{P}_{\text {available }}\left(\mathrm{mg}_{\mathrm{g}} \cdot \mathrm{kg}^{-1}\right)$ & $225 \pm 34$ & $169 \pm 9$ \\
\hline
\end{tabular}

$\mathrm{pH}_{\mathrm{W}}$ is $\mathrm{pH}$ measured in water; $\mathrm{C}$ is total carbon; $\mathrm{N}$ is total nitrogen; $\mathrm{eCEC}$ is the effective cation exchange capacity $\left(\mathrm{cmol}_{\mathrm{C}} \cdot \mathrm{kg}^{-1}\right) ; \mathrm{X}_{\mathrm{e}}$ is exchangeable concentration of the element. 


\subsection{Estimation of Bacterial Community Growth}

Bacterial community growth was estimated extracting the bacterial community from all soil microcosms, using homogenization/centrifugation and leucine (Leu) incorporation into bacteria [39], in accordance with the method of Bååth et al. [40]. The method determined the bacterial protein synthesis, which was used as a proxy for bacterial growth, by estimating ${ }^{3} \mathrm{H}$-Leu incorporation into extracted bacteria. Briefly, $1 \mathrm{~g}$ of soil (fresh weight) was mixed with $10 \mathrm{~mL}$ of distilled water using a multi-vortex shaker for $3 \mathrm{~min}$, at maximum intensity, followed by low-speed centrifugation at $1000 \times g$ for $10 \mathrm{~min}$, creating a bacterial suspension in the supernatant. Then, an aliquot of this bacterial suspension $(1.5 \mathrm{~mL})$ was transferred to a $2-\mathrm{mL}$ micro-centrifugation tube, and $2 \mu \mathrm{L}$ of $\left[{ }^{3} \mathrm{H}\right]$ Leu (3.7 MBq. $\mathrm{mL}^{-1}$ and $0.574 \mathrm{TBq} \cdot \mathrm{mmol}^{-1}$; Perkin Elmer, Waltham, MA, USA) was added together with non-labeled Leu to each tube, resulting in 275-nM Leu in the bacterial suspensions. Then, the micro-tubes were incubated for $2 \mathrm{~h}$ at $22{ }^{\circ} \mathrm{C}$ in the dark, and the growth stopped with $75 \mu \mathrm{L}$ of $100 \%$ trichloroacetic acid after the incubation period. Later, the bacteria in the tubes were washed as described by Bååth et al. [40]. Finally, ${ }^{3} \mathrm{H}$ radioactivity was determined using scintillation liquid counting (Tri-Carb 2810 TR, Perkin Elmer, Waltham, MA, USA).

\subsection{Data Analysis and Statistics}

Data corresponding to the bacterial growth estimated as a function of SDZ concentration were normalized respect to the control (sample without antibiotic) for each soil, and plotted (as relative bacterial growth vs. log antibiotic concentration) using results obtained for each soil mixture and the antibiotic.

The statistical significance of differences between the control soil and soil samples spiked with the various SDZ concentrations was estimated using one-way ANOVA and Dunnet's post hoc test $(p<0.05)$. The statistical analyses were performed using IBM SPSS statistics 23.0 and JMP Pro 13.0 for Mac (SAS Institute Inc., Cary, NC, USA).

\section{Results and Discussion}

Figures 1 and 2 show the relative growth of soil bacterial communities in response to increasing concentrations of sulfadiazine $\left(0-2000 \mathrm{mg} \cdot \mathrm{kg}^{-1}\right)$ for different times of incubation (2-100 days), i.e., the figures show the effect of time on the toxicity exerted by sulfadiazine on the growth of bacterial communities. In the short-term, after two days of incubation, the addition of SDZ to soil 1 (Figure 1) did not affect negatively the growth of bacterial communities for any of the concentrations tested (up to $2000 \mathrm{mg} \cdot \mathrm{kg}^{-1}$ ). In fact, the bacterial community growth even increased for most of the concentrations used, although those increases were not statistically significant. However, in soil 2 (Figure 2), the bacterial community growth decreased for the higher SDZ doses, achieving significant reductions in relation to the control for the doses of 500 and $2000 \mathrm{mg} \cdot \mathrm{kg}^{-1}$. However, the magnitude of decrease for the highest SDZ dose $\left(2000 \mathrm{mg} \cdot \mathrm{kg}^{-1}\right)$ was relatively low $(32 \%)$, if compared with results previously reported for other antibiotics, such as tylosin [33,41], tetracyclines [22,28,29,33], or streptomycin [22]. It is worth noting that, despite the low adsorption previously reported for SDZ onto soils [42], the short-term effect of SDZ on bacterial community growth was relatively low. This unmarked toxicity may be attributed to the scarce solubility of SDZ $[6,43,44]$. Demoling et al. [27] found a reduction of bacterial community growth reaching around $55 \%$ in a soil amended with $500 \mathrm{mg} \cdot \mathrm{kg}^{-1}$ of another sulfonamide antibiotic (sulfamethoxazole), which meant a higher toxicity than that found for SDZ in the present work. The difference may be also attributed to their variated solubility values, since that of sulfamethoxazole $\left(610 \mathrm{mg} \cdot \mathrm{L}^{-1}\right)$ was one order of magnitude higher than SDZ solubility $\left(77 \mathrm{mg} \cdot \mathrm{L}^{-1}\right)$ [45]. In other works, using different endpoints, a low direct effect on

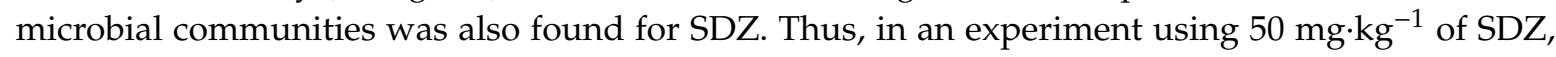
no effect was found on respiration activity or bacterial community structure [19]. In another work, using PLFAs (Phospholipid Fatty Acids), Hammesfahr et al. [20] found an increase in microbial biomass 
(total PLFAs) when the soil was polluted with $100 \mathrm{mg} \cdot \mathrm{kg}^{-1}$ of the antibiotic, but a modification in the microbial community structure was also reported. Overall, the short-term results found in the present work, together with results from previous works, suggest that SDZ accumulation in soils causes low negative direct effects on soil microbial communities.

Figure 1 also shows a clear increase of SDZ toxicity over time in the experiments performed with soil 1. For various of the incubation times, the increases in toxicity were not significant, but after 100 days of incubation, the increase in toxicity became significant for SDZ concentrations $\geq 125 \mathrm{mg} \cdot \mathrm{kg}^{-1}$. For soil 2 , SDZ toxicity also increased with time, achieving significant decreases in the bacterial community growth after 100 days of incubation when SDZ concentrations were $\geq 7.8 \mathrm{mg} \cdot \mathrm{kg}^{-1}$. These results showed that SDZ toxicity may be not only persistent with time, but also may increase, i.e., using only short-term experiments, the research may underestimate the toxicity of this antibiotic. These results can be considered somehow surprising, since organic compounds (including antibiotics) generally decrease their toxicity with time. As examples, decreases in toxicity of organic compounds were previously found for atrazine when examining effects on microbial biomass [46], as well as for fomesafen regarding effects on urease activity [47], or tetracycline regarding its effect on bacterial community tolerance $[28,29]$. This decrease is reasonable, since the concentrations of these organic compounds were reduced with time due to degradation [48], or suffered immobilization in the soil via ageing processes [49], or microbial communities developed tolerance to the organic compound [50]. For SDZ, Hammesfahr et al. [20] found that the concentration of the antibiotic in soils highly decreased with time, i.e., its half-life in soils was between 5.6-8.5 days for a SDZ concentration of $100 \mathrm{mg} \cdot \mathrm{kg}^{-1}$. Therefore, a decrease in toxicity was expected. However, in the soils of the present study the toxicity was significant for a similar SDZ concentration $\left(125 \mathrm{mg} \cdot \mathrm{kg}^{-1}\right.$, or even lower) after 100 days of incubation. Therefore, the persistence/increase of toxicity initially caused by SDZ with time may continue in the soil even when the antibiotic has disappeared from that environment.

The increases of toxicity with time for organic compounds are less common, but were recently described for the herbicide terbutryn [31]. However, to our knowledge, it is the first time that the increase of toxicity on soil microbial communities with time has been described for a veterinary antibiotic. We hypothesized two possible mechanisms for this increase in toxicity, although it would need further future studies. One possibility is that some compounds resulting from SDZ degradation became more toxic than SDZ itself, similar to the case described for carbendazim, which is a metabolite derived from the fungicide benomyl [51]. As SDZ was progressively degraded, the concentration of degradation products increased, with a subsequent possible rise in toxicity with time. Two major metabolites of SDZ are N4-acetylsulfadiazine and 4-hydroxysulfadiazine [52], but their toxicity on soil microbial communities has not yet been studied. Another possibility could be a chronic effect of SDZ and its metabolites on microbial growth, due long-term microbial stress. In this hypothesis, SDZ and its metabolites would have little or no effects in the short-term, but negative effects would appear with time, due to high metabolic requirements affecting to the microorganisms when fighting against the toxicants present in that medium [53]. More future research would be needed to clarify the mechanism behind the increase/persistence of SDZ toxicity with time of exposure.

The results found in the present work have important implications for the ecotoxicological assessment of antibiotic effects on bacterial communities and risk assessment analyses (ERA). Current ERA protocols $[54,55]$ assume that the impacts of toxicants will decrease with incubation time [56], and therefore, in the case of sulfadiazine, they may underestimate the risks associated with the accumulation of this antibiotic in soils. In view of that, it is important to reconsider the duration of current standardized ecotoxicological tests in order to propose longer periods of incubation. Time extensions, together with the use of more sensitive endpoints, may contribute to improve ERA analyses and overcome the recent criticisms received by current methods due to overlooking important effects of toxicant on soil microbiota [57]. 


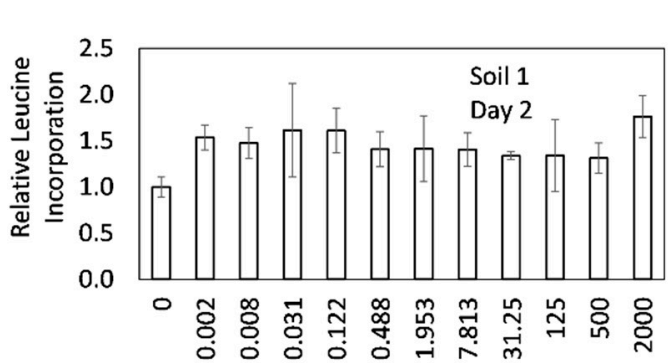

[SDZ] $\mathrm{mg} \cdot \mathrm{kg}^{-1}$

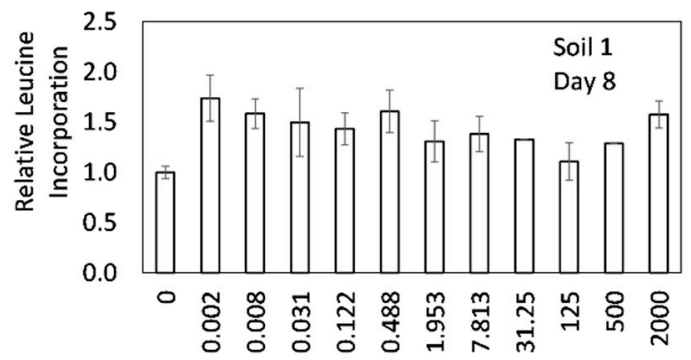

[SDZ] $\mathrm{mg} \cdot \mathrm{kg}^{-1}$

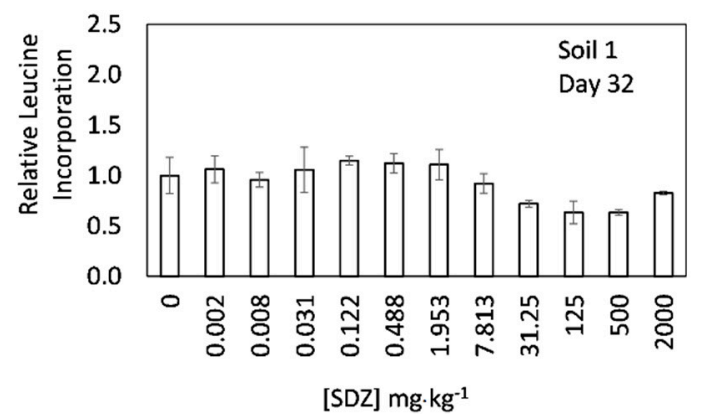

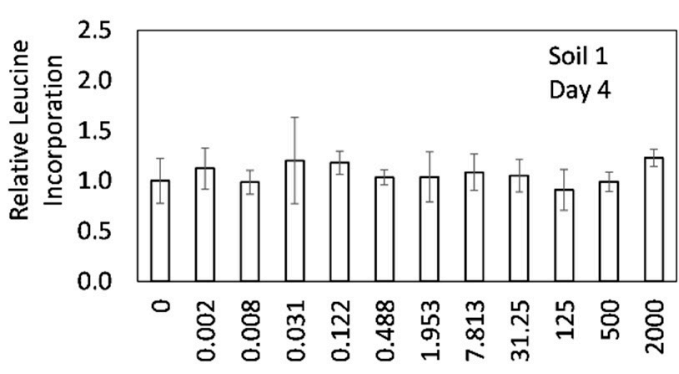

[SDZ] $\mathrm{mg} \cdot \mathrm{kg}^{-1}$

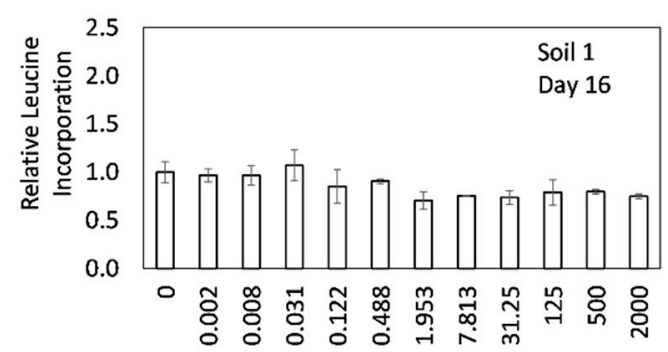

[SDZ] $\mathrm{mg} \cdot \mathrm{kg}^{-1}$

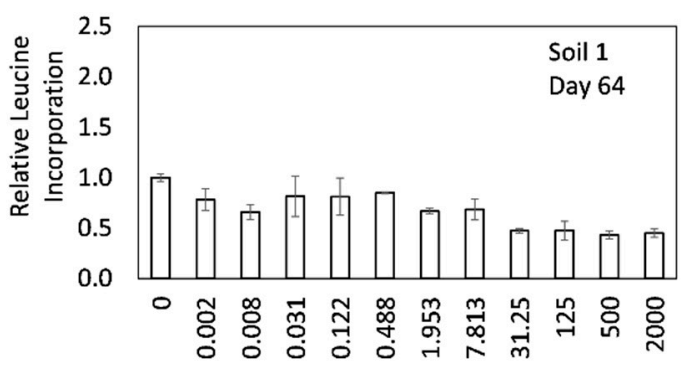

[SDZ] $\mathrm{mg} \cdot \mathrm{kg}^{-1}$

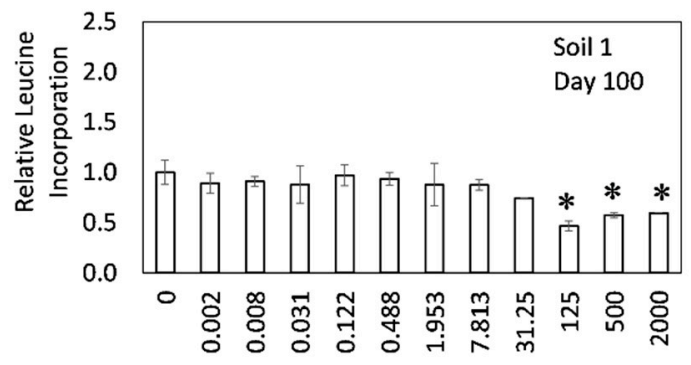

[SDZ] $\mathrm{mg} \cdot \mathrm{kg}^{-1}$

Figure 1. Relative bacterial community growth (estimated as ${ }^{3} \mathrm{H}$ Leucine incorporation) in soil 1 as a function of sulfadiazine concentration added for different incubation times. Error bars show the standard errors from average values $(n=3)$, and * indicates significant differences with respect to the control $(p<0.05)$. 

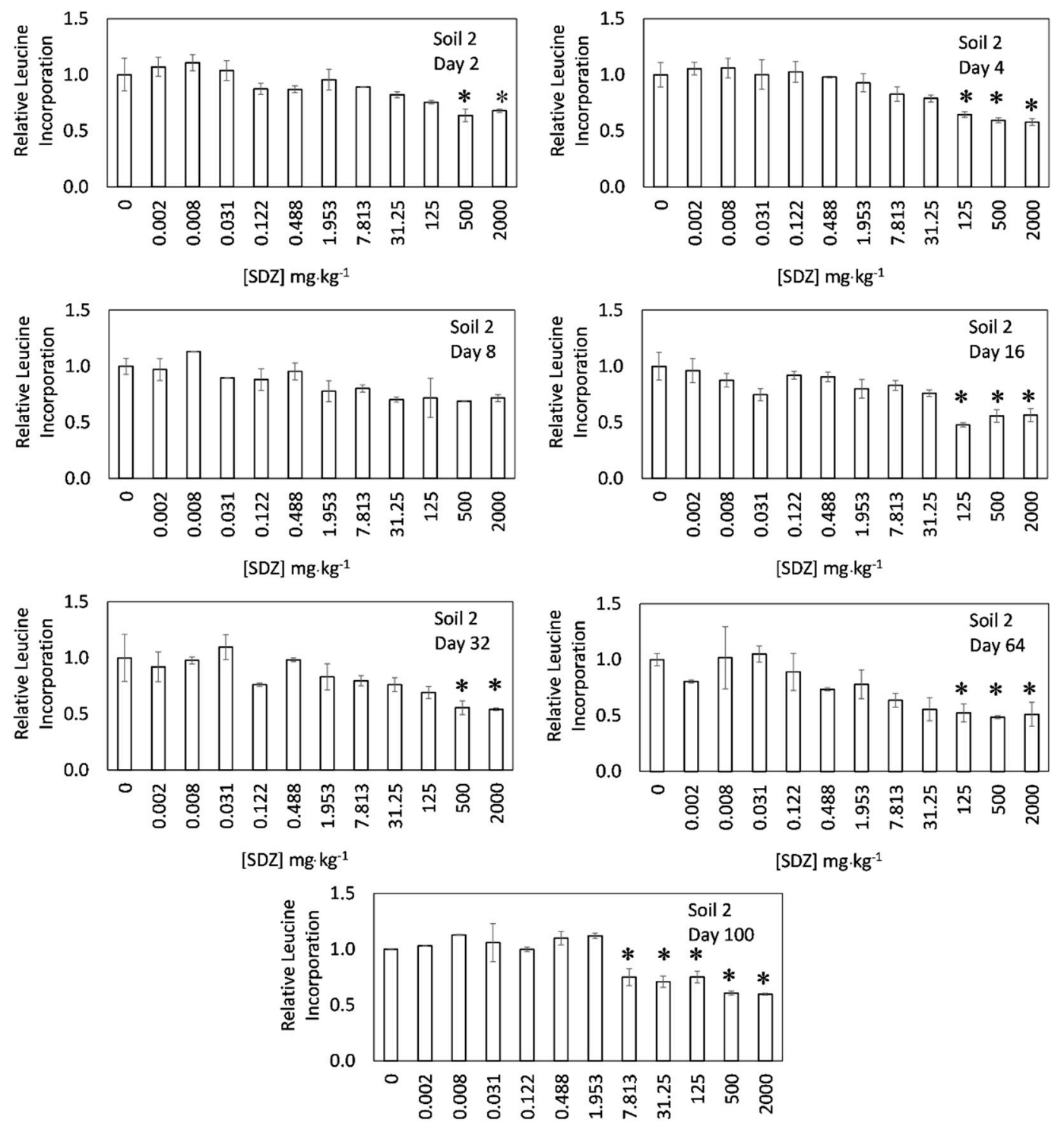

[SDZ] $\mathrm{mg} \cdot \mathrm{kg}^{-1}$

Figure 2. Relative bacterial community growth (estimated as ${ }^{3} \mathrm{H}$ Leucine incorporation) in soil 2 as a function of sulfadiazine concentration for different incubation times. Error bars show the standard errors from average values $(n=3)$, and * indicates significant differences with respect to the control $(p<0.05)$.

\section{Conclusions}

In the present work, using short incubation times to check SDZ toxicity would result in a conclusion indicating the absence of negative effects of SDZ on soil bacterial growth, even at concentrations as high as $2000 \mathrm{mg} \cdot \mathrm{kg}^{-1}$ for one of the soils tested (soil 1). However, a relevant finding of this study is that, for long incubation times (100 days), toxicity effects could be detected even for concentrations lower than $10 \mathrm{mg} \cdot \mathrm{kg}^{-1}$ of SDZ. Taking into account that most studies regarding toxic effects on soil microorganisms are performed in the short- or medium-term, they may underestimate overall toxicity that could affect to soil microorganisms. Therefore, it is suggested that, for potentially toxic substances, risk assessment methodologies and procedures should be adapted to take into consideration the possible existence of long-term effects, even in cases of absence of short-term effects. It could be of relevance for studies in relation to both environment aspects and public health. These findings are of special importance for improving the current procedures dealing with antibiotics' risk assessment in soils, suggesting the 
need for new methodologies that take into account potential delayed negative effects of antibiotics on soil microbes. Therefore, further research is needed to finally propose appropriate changes that could improve the current methodologies.

Author Contributions: Conceptualization, M.A.-E. and D.F.-C.; Formal analysis, V.S.-M. and L.R.-G.; Funding acquisition, A.N.-D. and M.A.-E.; Investigation, V.S.-M. and L.R.-G.; Methodology, M.D.-R. and D.F.-C.; Writing-original draft, V.S.-M., M.D.-R. and M.A.-E.; Writing—review \& editing, A.N.-D. and D.F.-C. All authors have read and agreed to the published version of the manuscript.

Funding: This study has been funded by the Spanish Ministry of Economy and Competitiveness through the projects CGL2015-67333-C2-1-R and -2-R (FEDER Funds), and by Xunta de Galicia via CITACA Strategic Partnership (ED431E 2018/07) and BV1 research group (ED431C 2017/62-GRC). David Fernández Calviño holds a Ramón y Cajal contract (RYC-2016-20411) financed by the Spanish Ministry of Economy Industry and Competitiveness. Vanesa Santás Miguel holds a pre-doctoral fellowship founded by the University of Vigo.

Conflicts of Interest: The authors declare no conflict of interest.

\section{References}

1. European Commission (EC); Directorate-General (DG) XXIV; Consumer Policy and Consumer Health Protection. Opinion of the Scientific Steering Committee on Antimicrobial Resistance; Report of the European Commission, DG XXIV, Consumer Policy and Consumer Health Protection; European Commission: Brussels, Belgium, 1999.

2. Sarmah, A.K.; Meyer, M.T.; Boxall, A.B. A global perspective on the use, sales, exposure pathways, occurrence, fate and effects of veterinary antibiotics (VAs) in the environment. Chemosphere 2006, 65, 725-759. [CrossRef] [PubMed]

3. Hamscher, G.; Sczesny, S.; Höper, H.; Nau, H. Determination of persistent tetracycline residues in soil fertilized with liquid manure by high-performance liquid chromatography with electrospray ionization tandem mass spectrometry. Anal. Chem. 2002, 74, 1509-1518. [CrossRef] [PubMed]

4. Ungemach, F.R. Figures on quantities of antibacterials used for different purposes in the EU countries and interpretation. Acta Vet. Scand. Suppl. 2000, 93, 89-97. [PubMed]

5. Halling-Sørensen, B.N.N.S.; Nielsen, S.N.; Lanzky, P.F.; Ingerslev, F.; Lützhøft, H.H.; Jørgensen, S.E. Occurrence, fate and effects of pharmaceutical substances in the environment-A review. Chemosphere 1998, 36, 357-393. [CrossRef]

6. Thiele-Bruhn, S. Pharmaceutical antibiotic compounds in soils-A review. J. Plant Nutr. Soil Sci. 2003, 166, 145-167. [CrossRef]

7. Ter Laak, T.L.; Gebbink, W.A.; Tolls, J. The effect of $\mathrm{pH}$ and ionic strength on the sorption of sulfachloropyridazine, tylosin, and oxytetracycline to soil. Environ. Toxicol. Chem. 2006, 25, 904-911. [CrossRef]

8. De la Torre, A.; Iglesias, I.; Carballo, M.; Ramírez, P.; Muñoz, M.J. An approach for mapping the vulnerability of European Union soils to antibiotic contamination. Sci. Total Environ. 2012, 414, 672-679. [CrossRef]

9. Burkhardt, M.; Stamm, C.; Waul, C.; Singer, H.; Müller, S. Surface runoff and transport of sulfonamide antibiotics and tracers on manured grassland. J. Environ. Qual. 2005, 34, 1363-1371. [CrossRef]

10. Brown, G.M. The biosynthesis of folic acid. 2: Inhibition by sulfonamides. J. Biol. Chem. 1962, 237, 536-540.

11. Merck. The Merck Index, 13rd ed.; O'Neil, M.J., Smith, A., Heckelmann, P.E., Eds.; Merck: Readington Township, NJ, USA, 2001.

12. Petrie, W.A. Antimicrobial Agents Sulfonamides, Trimethoprim Sulfamethoxazole, Quinolones, and Agents for Urinary Tract Infections. In Goodman and Gilman's: The Pharmacological Basis of Therapeutics, 10th ed.; Hardman, J.G., Limbird, L.E., Gilman, A.G., Eds.; McGraw-Hill: New York, NY, USA, 2001; pp. 1171-1188.

13. Hammesfahr, U.; Bierl, R.; Thiele-Bruhn, S. Combined effects of the antibiotic sulfadiazine and liquid manure on the soil microbial-community structure and functions. J. Plant Nutr. Soil Sci. 2011, 174, 614-623. [CrossRef]

14. Xu, Y.; Yu, W.; Ma, Q.; Wang, J.; Zhou, H.; Jiang, C. The combined effect of sulfadiazine and copper on soil microbial activity and community structure. Ecotoxicol. Environ. Saf. 2016, 134, 43-52. [CrossRef] [PubMed]

15. Brandt, K.K.; Sjøholm, O.R.; Krogh, K.A.; Halling-Sørensen, B.; Nybroe, O. Increased pollution-induced bacterial community tolerance to sulfadiazine in soil hotspots amended with artificial root exudates. Environ. Sci. Technol. 2009, 43, 2963-2968. [CrossRef] [PubMed] 
16. Luo, Y.; Mao, D.Q.; Rysz, M.; Zhou, D.X.; Zhang, H.J.; Xu, L.; Alvarez, P.J.J. Trends in antibiotic resistance genes occurrence in the Haihe River, China. Environ. Sci. Technol. 2010, 44, 7220-7225. [CrossRef] [PubMed]

17. Qiao, M.; Ying, G.-G.; Singer, A.C.; Zhu, Y.-G. Review of antibiotic resistance in China and its environment. Environ. Int. 2018, 110, 160-172. [CrossRef] [PubMed]

18. Lo, C.-C. Effect of pesticides on soil microbial community. J. Environ. Sci. Health Part B Pestic. Contam. Agric. Wastes 2010, 45, 348-359. [CrossRef]

19. Zielezny, Y.; Groeneweg, J.; Vereecken, H.; Tappe, W. Impact of sulfadiazine and chlorotetracycline on soil bacterial community structure and respiratory activity. Soil Biol. Biochem. 2006, 38, 2372-2380. [CrossRef]

20. Hammesfahr, U.; Heuer, H.; Manzke, B.; Smalla, K.; Thiele-Bruhn, S. Impact of the antibiotic sulfadiazine and pig manure on the microbial community structure in agricultural soils. Soil Biol. Biochem. 2008, 40, 1583-1591. [CrossRef]

21. Cycon, M.; Mrozik, A.; Piotrowska-Seget, Z. Antibiotics in the soil environment-degradation and their impact on microbial activity and diversity. Front. Microbiol. 2019, 10, 338. [CrossRef]

22. Rousk, J.; Demoling, L.A.; Bååth, E. Contrasting short-term antibiotic effects on respiration and bacterial growth compromises the validity of the selective respiratory inhibition technique to distinguish fungi and bacteria. Microb. Ecol. 2009, 58, 75-85. [CrossRef]

23. Fernández-Calviño, D.; Rousk, J.; Bååth, E.; Bollmann, U.E.; Bester, K.; Brandt, K.K. Ecotoxicological assessment of propiconazole using soil bacterial and fungal growth assays. Appl. Soil Ecol. 2017, 115, 27-30. [CrossRef]

24. Fernández-Calviño, D.; Rousk, J.; Brookes, P.C.; Bååth, E. Bacterial pH-optima for growth track soil pH, but are higher than expected at low pH. Soil Biol. Biochem. 2011, 43, 1569-1575. [CrossRef]

25. Fernández-Calviño, D.; Bååth, E. Interaction between $\mathrm{pH}$ and $\mathrm{Cu}$ toxicity on fungal and bacterial performance in soil. Soil Biol. Biochem. 2016, 96, 20-29. [CrossRef]

26. Odukkathil, G.; Vasudevan, N. Toxicity and bioremediation of pesticides in agricultural soil. Rev. Environ. Sci. Bio/Technol. 2013, 12, 421-444. [CrossRef]

27. Demoling, L.A.; Bååth, E.; Greve, G.; Wouterse, M.; Schmitt, H. Effects of sulfamethoxazole on soil microbial communities after adding substrate. Soil Biol. Biochem. 2009, 41, 840-848. [CrossRef]

28. Santás-Miguel, V.; Arias-Estévez, M.; Díaz-Raviña, M.; Fernández-Sanjurjo, M.J.; Álvarez-Rodríguez, E.; Núñez-Delgado, A.; Fernández-Calviño, D. Interactions between soil properties and tetracycline toxicity affecting to bacterial community growth in agricultural soil. Appl. Soil Ecol. 2020, 147, 103437. [CrossRef]

29. Santás-Miguel, V.; Arias-Estévez, M.; Díaz-Raviña, M.; Fernández-Sanjurjo, M.J.; Álvarez-Rodríguez, E.; Núñez-Delgado, A.; Fernández-Calviño, D. Effect of oxytetracycline and chlortetracycline on bacterial community growth in agricultural soils. Agronomy 2020, 10, 1011. [CrossRef]

30. Marsh, J.A.P.; Davies, H.A. Effects of dichlorprop and mecoprop on respiration and transformation of nitrogen in two soils. Bull. Environ. Contam. Toxicol. 1981, 26, 108-115. [CrossRef]

31. Fernández-Calviño, D.; Rousk, J.; Bååth, E.; Bollmann, U.E.; Bester, K.; Brandt, K.K. Short-term toxicity assessment of a triazine herbicide (terbutryn) underestimates the sensitivity of soil microorganisms. Soil Biol. Biochem. 2020, in press.

32. Meisner, A.; Bååth, E.; Rousk, J. Microbial growth responses upon rewetting soil dried for four days or one year. Soil Biol. Biochem. 2013, 66, 188-192. [CrossRef]

33. Rousk, J.; Demoling, L.A.; Bahr, A.; Bååth, E. Examining the fungal and bacterial niche overlap using selective inhibitors in soil. FEMS Microbiol. Ecol. 2008, 63, 350-358. [CrossRef]

34. Conde-Cid, M.; Álvarez-Esmorís, C.; Paradelo, R.; Nóvoa-Muñoz, J.C.; Arias-Estevez, M.; Álvarez-Rodriguez, E.; Fernández-Sanjurjo, M.J.; Núñez-Delgado, A. Occurrence of tetracyclines and sulfonamides in manures. agricultural soils and crops from different areas in Galicia (NW Spain). J. Clean. Prod. 2018, 197, 491-500. [CrossRef]

35. Guitián, F.; Carballas, T. Técnicas de Análisis de Suelos; Pico Sacro: Santiago de Compostela, Spain, 1976; ISBN 8485170091, 9788485170098.

36. Sumner, M.E.; Miller, W.P. Cation exchange capacity and exchange coefficients. In Methods of Soil Analysis_Part 3: Chemical Methods; Soil Science Society of America: Madison, WI, USA, 1996; pp. 1201-1229.

37. Bertsch, P.M.; Bloom, P.R. Aluminum. In Methods of Soil Analysis_Part 3: Chemical Methods; Soil Science Society of America: Madison, WI, USA, 1996; pp. 517-550. 
38. Olsen, S.R.; Sommers, L.E. Phosphorus. In Methods of Soil Analysis_Part 2: Chemical and Microbiological Properties; Page, A.L., Miller, L.H., Keeney, D.R., Eds.; Soil Science Society of America: Madison, WI, USA, 1996.

39. Kirchman, D.; K'nees, E.; Hodson, R. Leucine incorporation and its potential as a measure of protein-synthesis by bacteria in natural aquatic systems. Appl. Environ. Microbiol. 1985, 49, 599-607. [CrossRef] [PubMed]

40. Bååth, E.; Pettersson, M.; Söderberg, K.H. Adaptation of a rapid and economical microcentrifugation method to measure thymidine and leucine incorporation by soil bacteria. Soil Biol. Biochem. 2001, 33, 1571-1574. [CrossRef]

41. Demoling, L.A.; Bååth, E. No long-term persistence of bacterial pollution-induced community tolerance in tylosin-polluted soil. Environ. Sci. Technol. 2008, 42, 6917-6921. [CrossRef] [PubMed]

42. Pikkemaat, M.G.; Yassin, H.; van der Fels, K.H.J.; Berendsen, B.J.A. Antibiotic Residues and Resistance in the Environment; RIKILT Report 2016.009; RIKILT Wageningen UR: Wageningen, The Netherlands, 2016.

43. Ingerslev, F.; Halling-Sørensen, B. Biodegradability properties of sulfonamides in activated sludge. Environ. Toxicol. Chem. 2000, 19, 2467-2473. [CrossRef]

44. Wang, S.; Wang, H. Adsorption behavior of antibiotic in soil environment: A critical review. Front. Environ. Sci. Eng. 2015, 9, 565-574. [CrossRef]

45. Chen, M.; Yi, Q.; Hong, J.; Zhang, L.; Lina, K.; Yuana, D. Simultaneous determination of 32 antibiotics and 12 pesticides in sediment using ultrasonic-assisted extraction and high performance liquid chromatography-tandem mass spectrometry. Anal. Methods 2015, 7, 1896. [CrossRef]

46. Bonfleur, E.J.; Tornisielo, V.L.; Regitano, J.B.; Lavorenti, A. The Effects of Glyphosate and Atrazine Mixture on Soil Microbial Population and Subsequent Impacts on Their Fate in a Tropical Soil. Water Air Soil Pollut. 2015, 226, 21. [CrossRef]

47. Zhang, Q.; Zhu, L.; Wang, J.; Xie, H.; Wang, J.; Wang, F.; Sun, F. Effects of fomesafen on soil enzyme activity, microbial population, and bacterial community composition. Environ. Monit. Assess. 2014, 186, 2801-2812. [CrossRef]

48. Kah, M.; Beulke, S.; Brown, C.C. Factors influencing degradation of pesticides in soil. J. Agric. Food Chem. 2007, 55, 4487-4492. [CrossRef]

49. Hatzinger, P.B.; Alexander, M. Effect of ageing of chemicals in soil on their biodegradability and extractability. Environ. Sci. Technol. 1995, 29, 537-545. [CrossRef] [PubMed]

50. Blanck, H. A critical review of procedures and approaches used for assessing pollution-induced community tolerance (PICT) in biotic communities. Hum. Ecol. Risk Assess. 2002, 8, 1003-1034. [CrossRef]

51. Clemens, G.P.; Sisler, H.D. Formation of a fungitoxic derivative from benlate. Phytopathology 1969, 59, 705-706.

52. Pfeifer, T.; Tuerk, J.; Fuchs, R. Structural Characterization of Sulfadiazine Metabolites Using H/D Exchange Combined with Various MS/MS Experiments. J. Am. Soc. Mass Spectrom. 2005, 16, 1687-1694. [CrossRef] [PubMed]

53. Schimel, J.; Balser, T.C.; Wallenstein, M. Microbial stress-response physiology and its implications for ecosystem functions. Ecology 2007, 88, 1386-1394. [CrossRef]

54. OECD. Soil Microorganisms: Nitrogen 194 Transformation Test. In OECD Guideline for the Testing of Chemicals; OECD: Paris, France, 2000.

55. OECD. Soil Microorganisms: Carbon Transformation Test. In OECD Guideline for the Testing of Chemicals; OECD: Paris, France, 2000.

56. EFSA Panel on Plant Protection Products and their Residues (PPR); Ockleford, C.; Adriaanse, P.; Berny, P.; Brock, T.; Duquesne, S.; Grilli, S.; Hernandez-Jerez, A.F.; Bennekou, S.H.; Klein, M.; et al. Scientific opinion addressing the state of the science on risk assessment of plant protection products for in-soil organisms. EFSA J. 2017, 15, 4690.

57. Thiour-Mauprivez, C.; Martin-Laurent, F.; Calvayrac, C.; Barthelmebs, L. Effects of herbicide on non-target microorganisms: Towards a new class of biomarkers? Sci. Total Environ. 2019, 684, 314-325. [CrossRef]

Publisher's Note: MDPI stays neutral with regard to jurisdictional claims in published maps and institutional affiliations. 